\title{
Accounting
}

\section{Impact of human resource accounting on organizations' financial performance in the context of SMEs}

\author{
Sania Khan ${ }^{\text {* }}$
}

${ }^{a}$ College of Business Administration Prince Sattam Bin Abdulaziz University, Al Kharj, Saudi Arabia

\section{H R O N I C L E}

Article history:

Received: October 28, 2020

Received in revised format:

November 282020

Accepted: December 22, 2020

Available online:

December 22, 2020

Keywords:

Human resource accounting

Human capital efficiency

Financial performance

Organization profitability

Return on assets

Return on equity

\section{A B S T R A C T}

This study aims to investigate the impact of human resource accounting (HRA) on the overall performance of the organization. By presenting the details of HRA the study identifies various dimensions of organizations' financial aspects viz., human capital efficiency, organization profitability, return on asset, and return on equity. To understand the impact of various measurements, the study collected required data from 268 responses of human resource and finance departments of SME firms and analyzed the data using linear regression and the result of ANOVA and coefficient values illustrated there is a positive significant effect of HRA on human capital efficiency, organization profitability and return on equity. This is evident that the SME firms in Saudi Arabia are aware of the benefits on HRA of the organization and the only concern is it needs rapid implementation initiatives from the management which is possible with wide awareness across the nation. However, there is no significant effect of HRA on return on assets. This study contributes to the SME firms, human resource departments, and managerial decision-makers to understand the HRA concept and its usefulness to a make positive difference in their financial statements.

\section{Introduction}

Taking decisions related to human resources (HR) had never been so easy without proper knowledge of cost-benefit analysis. As most of the firms anticipate cost-cutting, cost-benefit analysis becomes a powerful tool to assess an extensive range of business prospects. Also, this cost-benefit analysis is proven to calculate and produce promising results against accompanying costs of investment in many HR activities viz., employee training, automation of HR process, etc. across various firms. However, most of the firms currently perceive much easy to look into the cost related to HR planning and implementations, however often face challenges while inspecting benefits in terms of monetary value. It is hard to justify the human capital investment, unless the HR departments shift their views from the process costs to financial return and benefits. While the cost aspects include both direct and indirect costs like office supplies, payments to trainers, developing a new system, loss of employees' productive time; benefit aspects include an increase in production, improve quality and efficiency, generation of firms' revenue. Therefore, the HRA approach is imperative and crucial to bridge a gap between a firm's human capital and expected cost-benefit outcomes to accomplish critical objectives. On the other side, it promises to assist the HR departments to develop comparative alternatives. Based on this, the human resource experts are developing new HR models to implement in their business with the hope to serve their employees and firms better and create a difference in the market with a deep insight into future benefits. This motivated the author to explore more on HRA and identify which factors logically proven to be the driving factors in the HR arena. Though there were limited attempts especially in Saudi Arabia answering few research questions such as the reasons why firms consider HRA, what is its role and what do they accomplish out of it, the future impact of HRA on firms' profitability, current and future goals of a firm and their consequences after executing HRA. There exists a research gap in understanding what are the most

* Corresponding author.

E-mail address: $\underline{\text { sa.khan@psau.edu.sa }}$ (S. Khan) 
essential HRA determinants that are driving firms' performance in terms of profitability. Therefore, this study identifies all the components of HRA that composes in assessing human assets and human resource valuation models.

\section{Statement of Problem}

Though it was cited in Enofe et al. (2013) study that HRA concept is very popular, it lacks general acceptability and still many organizations are attempting to understand it conceptually. The recognition of HRA is lagging as there are no accounting standards that guide the consideration dimensions of HR in financial statements. However, it is considered that human resource is the intellectual asset of any firm as their employees' competencies and capabilities determine the achievement of an organization (Bokeno, 2011). Some organization's financial statements demonstrate the huge amount of money spent on employee development like training, employee welfare, medical, and insurance are not regarded as an investment rather those costs are company expenses for a particular period which will affect the firm's value and profit. The foremost issue is how to assess the worth and economic value of employees to the organization and how to determine the cost issues. Therefore, a well-established system of HRA could account for managerial decisions internally and investors' decisions externally (Fajana, 2002). Rao (2000) asserted that prospective investors can easily decide on their investment in various firms based on investigating the strength and utilization of human assets. It has been observed very few developed and developing countries like Canada, United States, Mexico, and India have implemented HRA and there needs to be a massive consideration globally to recognize and standardize the HRA concept to bring changes in their financial statements. While computing employees' worth in terms of experience, qualification, and contribution to the organization is a key limitation, it is also hard to predict how long the organization can retain its employees could make it challenging to compute the value for more than a year. Meshack et al. (2013) reported many researchers suggested various approaches to valuing employees. Brumment suggested the original cost method; Likert recommended the replacement cost method; Flamholtz, Bullen and Hua developed the present value method but so far, no method is accepted globally. Till today the HRA concept is mostly restricted to academics but the practical implementation in firms is not observed actively. Many past researchers (Bowers, 1973; Likert, 1967; Schulz, 1961; Flamholz et al., 2002) research on bringing the worth of human in the firm's financial statements. As such the HRA concept is very new in Saudi Arabia. Hence, this study was conducted to bridge the gap by investigating the impact of HRA on the overall performance of small and medium enterprises (SME) of Saudi Arabia.

\section{Objectives of the Study}

In visualizing the concept of HRA, the study attempted to address the identified gaps in the context of small and medium-sized enterprises. In this regard, the general objectives are to explore if HRA contributes as a potential measurement tool of human capital efficiency and to conclude if HRA will help improving organizations' profitability and make difference in a firm's financial statements. Therefore, the specific objectives are as below.

1. To determine the impact of HRA on human capital efficiency,

2. To determine the impact of HRA on organization profitability,

3. To determine the impact of HRA on return on asset,

4. To determine the impact of HRA on return on equity.

\section{Literature review}

Unlike the other factors like land, capital which are included in financial statements, the organizations do not include labor into financial accounts. The HRA is the method of recognizing, recording and reporting the investment made on human resources in an organization which are currently not included in bookkeeping practices. In other words, these are accounted for as additional expenses of the company. There are multiple definitions from different authors. The American Accounting Association defined HRA as a process of recognizing, computing, and connecting information about employees to enable better management within the organization. Therefore, it can also be defined as the knowledge or intellectual capital the employees hold during their span of employment and produce goods and services or ideas in a competitive or non-competitive environment of an organization. Flamholtz (1985) defined HRA as the process of calculating the cost incurred by an organization on its employees for recruitment, selection, hiring and training. So, it deals with computing the economic value of the employees in an organization. Lau and Lau (1978) and Friedman and Lev (1974) defined HRA as a systematic process of asset creation and measuring the asset value of the workforce. Abubakar, S. (2009) viewed HRA as a measurement tool to communicate about the cost and value of employees of an organization. By concluding all the available definitions of HRA, we define the concept as a calculation method of cost and value of employees in the firm's financial statements as an intangible asset.

\subsection{Human Resource Accounting Measurements}

It is often challenging to assign a monetary value to human assets from various dimensions. Various approaches to the measurement of human assets are of two types namely Cost-Based Approach and Economic Based Approach. 


\section{A. Cost-Based Approach}

In the cost-based approach, the cost is the amount that any firms spend in the expectation of benefit or provision of services. Hence cost can be viewed as an expense element or and an asset element too. The difference between both is expense may give benefits in the current accounting period, whereas asset element is projected to give future benefits to the organization. So cost-based approach is further including four models.

i. Historical cost model: It is the cost incurred on human resources to procure the employees. It includes the cost of recruitment, selection, hiring, training, and development. These costs are the investments and expected to produce benefits through the utilization of employees. In case the asset results in early losses, it is recorded and written off to profit and loss of the current year and if human assets have extended life than expected, revision is made in the remuneration agenda. This historical cost of employees is much considered as fixed physical assets. Here the cost is seen in connection to the revenue and serves as a purpose for the firm's return on investment evaluation.

ii. Replacement cost model: It uses the estimation of current market value and is observed as the amount that has to be incurred on the current employees if they are to be replaced. This model is similar to the startup of a new firm and invests the money from scratch on employees if at all any replacement of workforce is needed with equal competencies. So it is considered as the cost incurred on replacing the terminated employee, which covers job posting or advertising cost, the administrative cost of pre-deployment of an employee, traveling and interview cost, other paperwork costs, etc. This cost is more reliable as it considers the current value of the firm's human assets its financial statement. It is proven to be the inefficiency of the firm to substitute the knowledge, competencies of employees.

iii. Opportunity cost model: This model considers the general concept of economic opportunity cost and hence is also known as the market value method. The asset value is calculated in comparison when there is an alternate opportunity to use it. This model applies to the human asset who are not available in plenty and of high demand. Therefore, the opportunity cost is determined by the job offer of an employee in comparison to its competitor organization.

iv. Standard cost model: The human asset is classified as groups based on their rank in job position and managerial levels. Then the monetary worth is calculated based on the category they belong to. This method uses the standard cost of various HR functions like recruitment, selection, traveling, and interview, training and development for each grade separately. So, this standard cost spent on the employee will be considered as the actual value of the employee. The drawback of this model is it does not consider the differences in the employee performance of the same group.

\section{B. Economic Approach}

This approach deals with the present value of human resource service which is expected to render in the future. This method measures the worth in two ways, namely monetary and non-monetary methods.

- Monetary Method: In the monetary method the worth of human resources in an organization is looked at as the present value to the firm. It computes the future earnings of the employees till their end of service or retirement and deducts from a predetermined value to obtain the present value of the future earnings.

- Present Value of Future Earning Model: This model was developed by Lev and Schwarts in 1971 and it considers the present value of the employee for the time he was employed in the organization. The current value of an individual employee is considered as the set of future services that he is going to provide the company till he remains in the organization. This method is quite complicated as it has to relies on assumptions of few things like the amount of employee's contribution to the firm; the rate of the amount to be discounted to calculate the present value; and the span of working years that the employee is expected to be in the organization.

- Reward Valuation Model: This model was developed by Flamholtz (1972) and the author believes the employee's expected conditional value is equal to the expected reliable value if he is sure that he remains in the organization throughout the lifetime of his service. This model was also developed on assumption that human resources will generate value as they grow and move hierarchically in the organizational roles providing service to the organization.

- Goodwill Model: This model was developed by Hermanson (1964), who believes in group estimation and the excess earnings of the organization above the average of the industry are from the unstated value of the workforce and resulting in excess returns.

- Economic Value Model: This model suggests the determination of group value by measuring their contribution to the total economic value of the organization. In this model, the forecasted future earnings will be deducted to present the current value of the organization and some part of the earning will be allotted to human resources for their efforts.

\subsection{Theoretical Background and Formulation of Research Hypotheses:}

Considering the above concept of HRA and the benefits it delivers to the organization, the theoretical aspects were discussed and formulated the testable hypotheses as below. 


\subsubsection{Human Capital Efficiency}

Human capital is one of the vital for an organization and influences the organization in the growth of productivity and proficiency. Verguwen \& Alem, 2005 said these are the worth of all employees in an organization whose rewards are associated with their utilization. Though the organization invests in their human resource the competencies and abilities of human resources are irregular and will go with individuals when they leave the organization (Roos \& Roos, 1997). Flamholtz (1973) asserted most organizations previously consider the plant and equipment as the core asset but the human resource is considered to be the real asset to any organization. Similarly, Bontis (2004) demonstrated the organization will gain a competitive advantage if the intellectual capital is efficient and those strengths are connected properly with the other organizational functions. Nielsen, Bukh, Mouritsen, \& Gormsen (2006) argued the intellectual capital is denoted by the inventory of human skills, knowledge, and management efficiency. Therefore, a research hypothesis is formulated as:

\section{$\mathrm{H}_{1}$ : HRA has a significant positive effect on the organizations' human capital efficiency (HCE).}

\subsubsection{Organization Profitability}

The concept of total cost productivity is the contribution of every business activity on profit generation for the company. Similarly, profitability also depends on the active utilization of every activity and resource available in the market. Harvard and Upton (1967), defined profitability as the benefit gained from the proper utilization of the invested money. Therefore, profitability is not an alternative word used for efficiency but it is regarded as a measurement tool of efficiency. Also, profitability is not only one illustrative of efficiency but there are also other attributes for efficiency like goodwill, trademark, global recognition, etc. So a net profit will represent a striking balance between the worth received and worth spent by the organization. Therefore, a research hypothesis is formulated as:

\section{$\mathrm{H}_{2}$ : HRA has a significant positive effect on the organization's profitability (OP).}

\subsubsection{Return on Asset}

The return on assets is an instrument to measure the effectiveness of an organization by proper utilization of its assets. It also helps in judging the better or poor functioning of the management and develops some cost control efforts for the management. While a high return on assets means the firm gaining a higher value of asses, it denotes the financial ratio to estimate the degree of profit generation. Riganto (2001) demonstrates, the higher the return on assets is the better the organizational performance because of the more the asset rate the better the returns on investment. Therefore, the return on assets is represented by net profit after taxes by the total assets of the firm. Therefore, a research hypothesis is formulated as:

\section{$\mathrm{H}_{3}$ : HRA has a significant positive effect on the return on asset (ROA).}

\subsubsection{Return on Equity}

Return on equity illustrates the degree of a firm that efficiently manages its capital and estimates the profitability of the invested amount. The higher the return on equity means the higher the profit growth and added working capital. Also, return on equity denotes the profitability of the own investment or business success. Return on equity is represented by the net profit after taxes by the total shareholder's equity. Therefore, a research hypothesis is formulated as:

\section{$\mathrm{H}_{4}$ : HRA has a significant positive effect on the return on equity (ROE).}

\section{Methodology}

This study emphasized to understand the influence of HRA on various components of organizational financial performance. This study is quantitative in nature as it collects primary data from HR and finance departments of various SMEs of different industries namely information technology, insurance, logistics, and supply chain, finance investment firms, retailing, automobiles, telecommunication, manufacturing, and construction. The HRA measurement items for this study were developed for this study using five-point Likert-scale ranging from 5 as strongly agree to 1 as strongly disagree. The questionnaire consists of closed-ended questions. The study used a random sampling method from different areas of Saudi SMEs. The survey questionnaire was administered to various respondents by email and with a follow-up email a second time within the span of two months. The target respondents belong to HR and finance departments who involve in HR expenses or budgeting and preparation of the firm's financial statements. This approach allowed the researcher to gather 284 responses and by case-wise deletion of incomplete data, it has resulted in 268 useful responses for further data analysis. To check the internal consistency reliability of measurement 
items, Cronbach's alpha was used by looking at the reliability coefficients. It was found all the items are all above 0.7 demonstrating the survey instrument is acceptable for data collection (Sekaran, 2005). Hence the data analysis was conducted and summarized the Cronbach's alpha values of the construct as shown in Table 1.

\section{Table 1}

Reliability Coefficients of the Components

\begin{tabular}{lll}
\hline Constructs & No. of Items & Cronbach's Alpha \\
\hline Human capital efficiency & 4 & 0.752 \\
Organization profitability & 4 & 0.781 \\
Return on asset & 4 & 0.865 \\
Return on equity & 4 & 0.725 \\
Human Resource Accounting & 5 & 0.784 \\
\hline
\end{tabular}

\section{Findings}

\subsection{Demographic Features}

The demographic characteristics of the respondents were analyzed and summarized in Fig. 1.

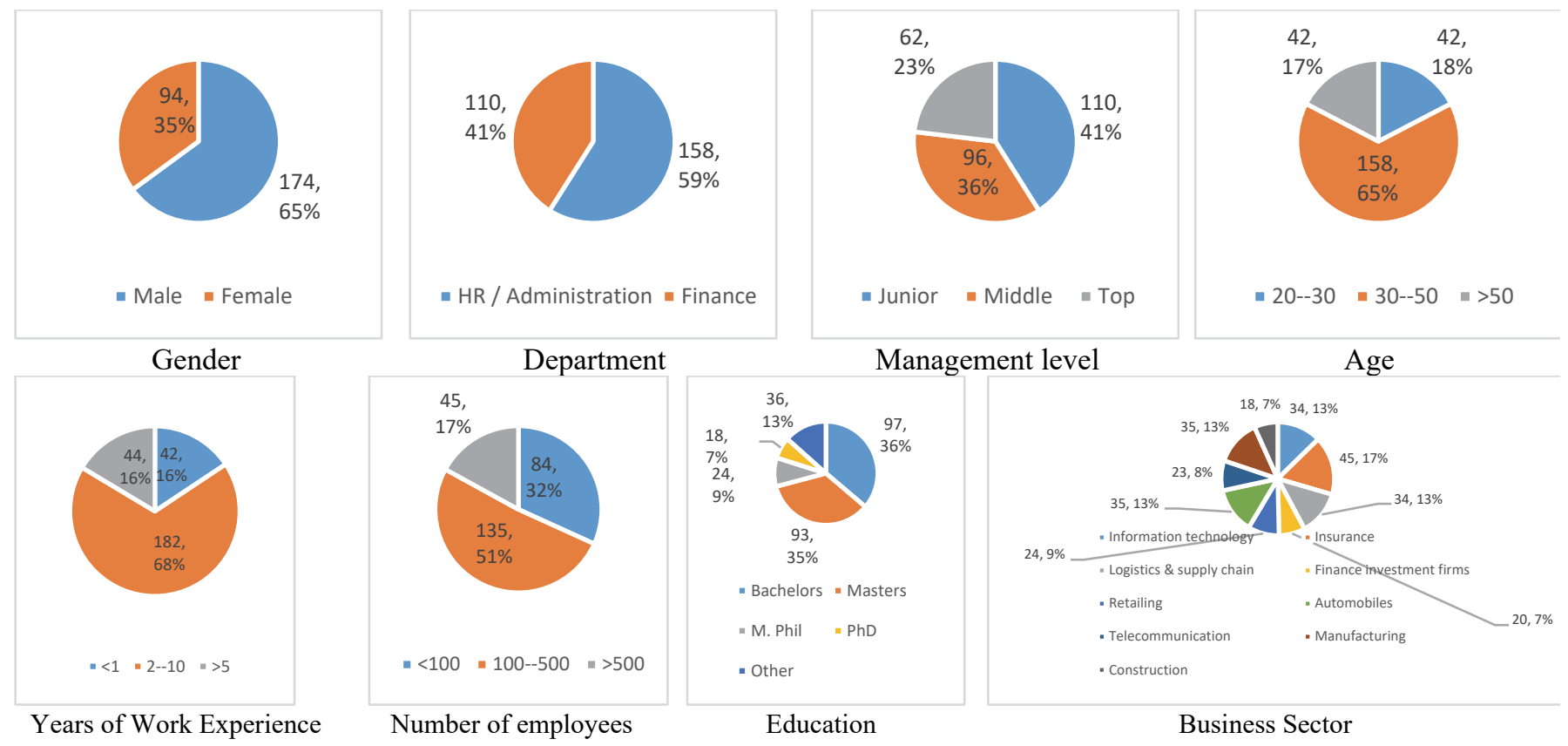

Fig. 1. Demographic Profile of the Respondents $(n=268)$

\subsection{Descriptive Statistics of the Components}

The descriptive statistics of the variables used in the study namely HRA, human capital efficiency, organizational profitability, return on asset and return on equity is consolidated in Table 2. The outcomes showed that SMEs' are aware of HRA concept and is commonly practiced only in few firms successfully (mean $=3.25, \mathrm{SD}=1.04$ ). The other economic variables in this study like human capital efficiency (mean $=3.58, \mathrm{SD}=1.22$ ); organizational profitability (mean $=3.46, \mathrm{SD}=1.13$ ); return on asset (mean $=3.66, \mathrm{SD}=1.58)$ and return on equity (mean $=3.63, \mathrm{SD}=1.42)$ which shows a moderate practice in SME organizations.

\section{Table 2}

Descriptive Statistics of the Components

\begin{tabular}{lll}
\hline Items & Mean & SD \\
\hline Human capital efficiency & 3.58 & 1.22 \\
Organization profitability & 3.46 & 1.13 \\
Return on asset & 3.66 & 1.58 \\
Return on equity & 3.63 & 1.42 \\
Human resource accounting & 3.25 & 1.04 \\
\hline
\end{tabular}




\subsubsection{Human Capital Efficiency (HCE)}

Among four items of human capital efficiency "strategic planning of human resource would lead to better benefits in long-run" has the highest mean score (mean $=3.95, \mathrm{SD}=1.06$ ) followed by "the organization success depends on the excellence of its human resources" (mean $=3.74, \mathrm{SD}=1.25)$ and "the quality of human resources would influence the firm's productivity" (mean $=3.27, \mathrm{SD}=1.42)$ and "the human competencies and approach will lead a firm to be more productive than other firms" $(\mathrm{mean}=$ $3.16, \mathrm{SD}=1.73)$.

\subsubsection{Organization Profitability (OP)}

This construct has four items, “the optimal utilization of firm's investment will increase the firm's profitability" (mean = 3.76, SD $=1.057$ ) has highest mean score followed by "firms reputation in the global market will lead to organization profitability" (mean $=3.57, \mathrm{SD}=1.068)$; and "proper utilization of physical resources of firm would increase the firm's profitability" (mean $=3.48$, $\mathrm{SD}=1.077)$; and the least mean score for "the net profit of an organization can be maintained by balancing the firm's profit and loss" $($ mean $=3.39, \mathrm{SD}=1.082)$.

\subsubsection{Return on asset (ROA)}

It was found SMEs are well aware that the employees are the greatest assets of an organization and investing on such assets will facilitate high returns. So the item-wise analysis demonstrated that "the quality on Intellectual capital within organization will result in high return on assets" obtained the highest mean score (mean $=3.98, \mathrm{SD}=1.01$ ); followed by "the cost incurred on training and development will yield the organization with high returns" (mean = 3.72, SD = 1.24); and "the firm's Human competencies will improve the firm's returns" (mean $=3.69, \mathrm{SD}=1.29)$; and "the human performance and productivity will lead to increase in returns" $($ mean $=3.52, \mathrm{SD}=1.48)$.

\subsubsection{Return on equity (ROE)}

Out of four items, "maximum utilization of the firm's human resource will lead to a good return on equity" (mean $=3.88$, SD $=$ $1.02)$; "it is the better idea that shareholders invest on employees leading to increase the firm's equity" (mean $=3.75$, SD $=1.15)$; "outsourcing the business activities will reduce the returns on equity" (mean $=3.68, \mathrm{SD}=1.18$ ); and "the firm must increase the working capital on their human assets to acquire a higher return on equity" (mean $=3.64, \mathrm{SD}=1.173)$.

\subsubsection{Human Resource Accounting (HRA)}

This construct includes four items to measure the successful implementation of HRA in SMEs. Among four items, "our organization is involved in HRA implementation" has the highest (mean $=4.25, \mathrm{SD}=0.832$ ); "HRA helps in personnel budgeting" $($ mean $=3.78, \mathrm{SD}=1.16)$; "HRA makes management more conscious of the importance of manpower" $($ mean $=3.59$, $\mathrm{SD}=1.19)$; and "HRA makes personnel decisions more objective" (mean $=3.47, \mathrm{SD}=1.154)$.

\subsection{Hypothesis Testing}

\section{H1: HRA has a significant positive effect on the organizations' human capital efficiency (HCE).}

Simple regression was conducted to test the hypothesis. The results presented in Table 3 considered HRA as regressed and HCE as a regressor. Results illustrated the independent variable explained only $17.9 \%$ of the variance $\left(\mathrm{R}^{2}=0.179\right)$, which was significantly low value. However, it is understood the remaining $82 \%(0.81)$ of variation was unexplained because of the effect of stochastic random variables. F-value is meaningful when the level of significance is five percent. Also, the coefficient value between HRA and HEC is 0.423 and is significant $(\alpha=0.05)$. Therefore, it is concluded the effect of HRA on HCE is significant and $H_{1}$ is accepted as the data supports the hypothesis.

Table 3

The results of regression analysis

\begin{tabular}{|c|c|c|c|c|c|}
\hline \multirow[t]{2}{*}{ Model } & \multicolumn{2}{|c|}{ Unstandardized coefficients } & \multicolumn{2}{|c|}{ Standardized coefficient } & \multirow[b]{2}{*}{ Sig. } \\
\hline & $\mathrm{B}$ & Std. Error & $\mathrm{B}$ & t-value & \\
\hline Constant & -240.343 & 359.038 & & -0.669 & 0.510 \\
\hline HRA & 57.934 & 25.903 & 0.423 & 2.237 & 0.035 \\
\hline
\end{tabular}


$\mathbf{H}_{2}$ : HRA has a significant positive effect on the organization's profitability (OP).

The results presented in Table 4 considered HRA as regressed and OP as a regressor. Results illustrated the independent variable explained only $26.5 \%$ of the variance $\left(\mathrm{R}^{2}=0.265\right)$, which is relatively a low number. ANOVA result shows the P-value of 0.029 which is significant at $\mathrm{P}<0.05$. Also, the coefficient value between HRA and OP is 0.514 and is significant at $\mathrm{p}<0.05$. Therefore, it is concluded the effect of HRA on OP is significant and $\mathrm{H} 2$ is accepted.

Table 4

The results of regression analysis

\begin{tabular}{|c|c|c|c|c|c|}
\hline \multirow[t]{2}{*}{ Model } & \multicolumn{2}{|c|}{ Unstandardized coefficients } & \multicolumn{2}{|c|}{ Standardized coefficient } & \multirow[b]{2}{*}{ Sig. } \\
\hline & $\mathrm{B}$ & Std. Error & $\mathrm{B}$ & t-value & \\
\hline Constant & 1.108 & 0.563 & & 1.967 & 0.067 \\
\hline HRA & 0.306 & 0.128 & 0.514 & 2.400 & 0.029 \\
\hline
\end{tabular}

H3: HRA has a significant positive effect on the return on asset (ROA).

The results presented in Table 5 considered HRA as regressed and ROA as a regressor. Results illustrated the independent variable explained $66.8 \%$ of the variance $\left(\mathrm{R}^{2}=0.668\right)$, which was significant. F-value $=16.105(0.000)$ is statistically significant. Surprisingly, the coefficient value between HRA and ROA is negative $(B=-0.817)$ and is significant at $p<0.05$. Because of the negative coefficient value, it is concluded the effect of HRA on ROA is negative and $\mathrm{H}_{3}$ is rejected as the data does not support the hypothesis.

Table 5

The results of regression analysis

\begin{tabular}{|c|c|c|c|c|c|}
\hline \multirow[t]{2}{*}{ Model } & \multicolumn{2}{|c|}{ Unstandardized coefficients } & \multicolumn{2}{|c|}{ Standardized coefficient } & \multirow[b]{2}{*}{ Sig. } \\
\hline & $\mathrm{B}$ & Std. Error & $\mathrm{B}$ & t-value & \\
\hline Constant & 7856642.174 & 37841636.85 & & 0.208 & 0.841 \\
\hline HRA & 0.651 & 0.162 & -0.817 & -4.013 & 0.004 \\
\hline
\end{tabular}

$\mathbf{H}_{4}$ : HRA has a significant positive effect on the return on equity (ROE).

The results presented in Table 6 considered HRA as regressed and ROE as a regressor. Results illustrated the independent variable explained about $78.5 \%$ of the variance $\left(\mathrm{R}^{2}=0.785\right)$, which is a significant value. ANOVA result shows the P-value is 0.000 and is highly significant. Also, the coefficient value between HRA and ROE is 0.886 and is significant at $p<0.05$. Therefore, it is concluded the effect of HRA on ROE is significant and $\mathrm{H}_{4}$ is accepted as the data supports the hypothesis.

Table 6

The results of regression analysis

\begin{tabular}{|c|c|c|c|c|c|}
\hline \multirow[t]{2}{*}{ Model } & \multicolumn{2}{|c|}{ Unstandardized coefficients } & \multicolumn{2}{|c|}{ Standardized coefficient } & \multirow[b]{2}{*}{ Sig. } \\
\hline & B & Std. Error & $\mathrm{B}$ & t-value & \\
\hline Constant & 0.621 & 0.038 & & 6.848 & 0.000 \\
\hline HRA & 0.837 & 0.004 & 0.886 & 227.487 & 0.000 \\
\hline
\end{tabular}

The overall findings demonstrated, Saudi Arabian SMEs well recognized the benefits of implementing HRA since they realize HRA will bring profits to the organization and will have a positive impact on ROE. Surprisingly it is observed they do not identify significant ROA through HRA. These findings are also consistent with myriads of research studies on HRA (Enofe, Mgbame, Otuya \& Ovie, 2013; Flamholz et al., 2002; Flamholz 1973).

\section{Conclusion}

This study was conducted to understand the impact of HRA on SMEs overall organization financial performance. It has upheld that in many SMEs' companies in Saudi Arabia, HRA is recognized as the major asset. Firms perceived they must invest on their employees rather than spending on other unproductive organizational activities. However, the SMEs did not find noticeable return on assets through HRA. Nevertheless, this study is evident that efforts on successful HRA implementation and practices will make significant positive changes in firms' financial statements.

\section{Limitations}

This study attempted to understand the impact of various HRA aspects on the overall organization. Further studies must develop strategies to overcome the losses that firms face during the employee's span of service in an organization. More studies need to 
be conducted to create organizational awareness and the benefits the firm could have by implementing the HRA concept in alignment with cost-cutting efforts in this modern global economy. As the HRA was found to hurt ROA, it was recommended to conduct more studies to validate this finding.

\section{References}

Abubakar, S. (2009). A critique of the concept of human resource accounting. Nigerian Journal of Accounting \& Finance, 1, 93105.

Bokeno, R.M. (2011). Putting people first: Employee retention and organizational performance. International Journal of Development, 25(1), 25-27

Bontis, N. (2004). National intellectual capital index: A United Nations initiative for the Arab region. Journal of Intellectual Capital, 5(1), 13-39.

Bowers, D. G. (1973). A review of Rensis Likert's "Improving the Accuracy of P/L Reports and Estimating the Change in Dollar Value of the Human Organization". Michigan Business Review, 25.

Enofe, A.O., Mgbame, C. Sunday O.S., \& Ovie, O. (2013). Human resources accounting disclosures in Nigeria quoted firms. Research Journal of Finance and Accounting, 4(13), 1-15

Fajana, S. (2002). Human Resource Management: An Introduction. Lagos: Labofin and Company.

Flamholtz E.G. (1972). Assessing the validality of a theory of human resource value: A field study. Journal of Accounting Research-Empirical Research in Accounting, 10, 241-266.

Flamholtz, E. (1973). Human resources accounting measuring potential replacement cost. Human Resource Management, 12(1), pp. 8-11.

Flamholtz, E. G., Bullen, M. L., \& Hua, W. (2002). Human resource accounting: A historical perspective and future implications. Management Decision, 40(10), 947 - 954.

Harvard, M \& Upton, K. (1967). Introduction to Business Finance. New York: Mc Graw-Hill.

Hermanson, R. M. (1964). Accounting for human assets. Michigan state university.

Likert, R. (1967). The Human Organisation - Its management and value. New York: McGraw Hill Book Company.

Meshack, I. S., Paymaster, B., \& Lyndon, E. (2013). An assessment of human resource capital and goodwill: A study of selected commercial banks in Nigeria. Journal of Business \& Management, 2(4), 36-48.

Nielsen, C., Bukh, P. N., Mouritsen, M. R, \& Gormsen, P. (2006). Intellectual capital statement on their way to the stock exchange. Journal of Intellectual Capital, 7(2), $221-240$.

Rao, T.V. (2000). Human Resource Development: concept and background, Human Resources Development: Experiences, interventions and strategies. New Delhi: Sage Publications.

Riganto, B. (2001). Dasar-Dasar Pembelanjaan Perusahaan. Yogyalaarta Prastowo, Dwi (2002). Analisis Lapora n Keuangan: Konoep dan Alikasi. YKPN: Yogyakarta.

Roos, G., \& Roos, J. (1997). Measuring your company’s intellectual performance, Long Range Planning. $30(3), 413-426$.

Schulz, T. W. (1961). Investment in human capital. The American Economic Review, 51(1), 1-17.

Verguwen, P.G., \& Alem, F.J. (2005). Annual report of disclosures in the Netherlands, France and Germany. Journal of Intellectual Capital, 6(1), 80-104.

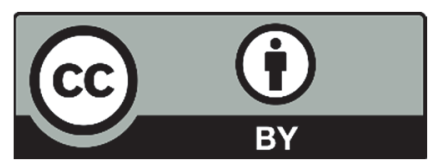

(C) 2021 by the authors; licensee Growing Science, Canada. This is an open access article distributed under the terms and conditions of the Creative Commons Attribution (CC-BY) license (http://creativecommons.org/licenses/by/4.0/). 